\section{Н.А. Минина}

Эволюция арендных отношений Новониколаевска и императорского Кабинета: к истории урбогенеза нового сибирского города на рубеже XIX-XX вв.

DOI: $10.31518 / 2618-9100-2018-2-5$

\section{УДК 63.3 (2Р5)}

Выходные данные для цитирования:

Минина Н.А. Эволюция арендных отношений Новониколаевска и императорского Кабинета: к истории урбогенеза нового сибирского города на рубеже XIX-XX вв. // Исторический курьер. 2018. № 2. Статья 5. URL:

http://istkurier.ru/data/2018/ISTKURIER-2018-2-05.pdf
Natalia Minina *

\section{Evolution of Land Lease Relations Between Novonikolaevsk and the Emperor's Cabinet: to the History of Urbogenesis of a New Siberian City in the Late 19th and Early 20th Century}

\author{
DOI: 10.31518/2618-9100-2018-2-5
}

How to cite:

Minina Natalia A. Evolution of land lease relations between Novonikolaevsk and the Emperor's Cabinet: to the history of urbogenesis of a new Siberian city in the late 19th and early 20th century // Historical courier, 2018, \# 2. Article 5. [Available online:]

http://istkurier.ru/data/2018/ISTKURIER-2018-2-05.pdf

Abstract: The article examines the history of land lease in Novonikolaevsk. The land under the town of Novonikolayevsk was the property of the royal family, administered by the Cabinet of His Majesty the Emperor (Emperor's Cabinet). The study is based on a wide range of sources, which allowed to give a comprehensive characteristic of the Cabinet's land lease system in Novonikolaevsk: to classify the types of lease depending on the tenant's activities on the land; to determine the conditions for leasing stated by the Cabinet; to analyze the change in rent rates during the entire period of land lease relations; and also to determine the period when the lease existed. The study provides quantitative data on rent rates - both for residential and commercial sections. It is shown that relations between the Cabinet and Novonikolaevsk have been poorly studied and, as a consequence, there are some wrong judgments, concerning for example the "illegality" of the settlement in its early years when it had no "official status". The Soviet historiography tended to be extremely negative about the Cabinet's landownership in Novonikolaevsk. In the post-soviet period, no new sources on this topic were introduced; therefore, the conclusions of Soviet historians remained until nowadays in the form of dogmas. In fact the establishment of land lease in the settlement legitimized automatically the latter's existence on the lands of the Cabinet. During the first decade, the land lease relations between the village and the Cabinet were the key factor determining both the administrative status of the Novonikolaevsk settlement and its economic development. Establishing the land lease relationships was, in fact, a temporary measure of the Cabinet, objectively caused by the youthful stage and the rapid development of the settlement, which was incapable at the first stage of its formation to run self-administration. On the other hand, the land lease presented the obvious commercial interest for the Cabinet. Due to the commercialization of the Cabinet's landholding, the rent rates were growing in Novonikolaevsk, but not as rapid as it is stated in historiography. To confirm this thesis, data is given concerning the increase in rent rates. An attempt was made to evaluate the effectiveness of land lease relations in the first decade of their establishment. Evolution of the Cabinet's rental policy included several stages from the introduction of land lease to the decision of its complete liquidation as a result of the purchase of Cabinet's lands by Novonikolaevsk.

\footnotetext{
* Минина Наталья Алексеевна, старший научный сотрудник Новосибирского государственного краеведческого музея (Россия), e-mail: mi.nata.12@yandex.ru

Minina Natalia Alekseyevna, senior researcher of the State Novosibirsk Historical Museum (Russia), e-mail: mi.nata.12@yandex.ru
} 
Keywords: the Cabinet of His Imperial Majesty; Cabinet's landownership; land lease; bailout.

The article has been received by the editor on 22.09.2018.

Full text of the article in Russian and references in English are available below.

Аннотация: В статье рассматривается процесс развития кабинетской земельной аренды в Новониколаевске. Исследование проведено с привлечением широкого круга источников, что позволило дать комплексную характеристику арендного хозяйства в Новониколаевске: классифицировать виды аренды в зависимости от деятельности арендатора на земельном участке, определить условия взимания аренды Кабинетом, проанализировать изменение арендных ставок в течение всего периода земельно-арендных отношений, а также определить временные рамки существования арендных отношений. В исследовании приведены количественные данные о ставках аренды - как на жилые усадьбы, так и на участки для торгово-промышленных заведений. Комплексный анализ источников позволил сделать вывод о слабой разработке в историографии земельно-арендных отношений Кабинета и Новониколаевска, и, как следствие, о существовании в этой теме некоторых заблуждений, как, например, «незаконность» поселка в первые годы и отсутствие у него «официального статуса». Данные выводы были характерны для советской историографии, крайне негативно оценивавшей кабинетское землевладение в Новониколаевске. В постсоветский период в научный оборот не были введены новые источники по данной теме, поэтому выводы советских историков в виде догм дошли до настоящего времени. В статье на фактическом материале доказывается, что установление аренды в поселке автоматически узаконивало его существование на землях Кабинета и давало ему административный статус арендного поселка Алтайского округа. В течение первого десятилетия земельно-арендные отношения поселка и Кабинета являлись ключевым фактором, определявшим как административное положение Новониколаевского поселка, так и его экономическое развитие. Арендное положение, по сути, являлось временной мерой Кабинета, объективно вызванной молодостью и быстрыми темпами возникновения и развития населенного пункта, неспособного на первом этапе к полноценному самоуправлению; с другой стороны, аренда находилась в зоне очевидных коммерческих интересов Кабинета. В связи с коммерциализацией кабинетского земельного хозяйства, арендные ставки в Новониколаевске росли, однако не такими темпами, как заявляется в историографии; для подтверждения этого тезиса приведены конкретные данные о повышении ставок аренды. Предпринята попытка оценить эффективность земельноарендных отношений в первое десятилетие, показать эволюцию арендной политики Кабинета - от введения земельной аренды до принятия решения о её полной ликвидации в результате выкупа Новониколаевском кабинетских земель.

Ключевые слова: Кабинет Его Величества; кабинетское землевладение; земельная аренда; выкуп.

Рубеж XIX-XX вв. ознаменовался в Сибири ростом новых городских центров. Самым заметным оказался Новониколаевск, который за полтора десятка лет встал в один ряд с крупными городами Сибири. В современных исследованиях отмечается, что Новониколаевск с его выдающимися темпами роста в градостроительном отношении представлял собой феномен большого города, причем единственного среди новых городов Российской империи ${ }^{1}$. Естественное быстрое развитие Новониколаевска стало возможным, в первую очередь, благодаря его выгодному экономико-географическому положению. В короткое время встал вопрос о преобразовании в город, так как официальное поселковое состояние не

\footnotetext{
1 Градостроительство России середины XIX - начала XX века. Книга 1. Общая характеристика и теоретические проблемы. М., Прогресс-Традиция, 2001. С. 27.
} 
соответствовало его реальному торгово-экономическому статусу. То есть, развитие Новониколаевска вполне отражало общие закономерности урбанизационного процесса в России, в том числе и такую его особенность, как несоответствие официального разграничения города и деревни, давно отмечаемого исследователями ${ }^{1}$.

Специфику урбогенезу Новониколаевска придавало расположение на землях, принадлежавших монарху - почти 15 лет он был плательщиком кабинетской земельной аренды. Рассматривая это явление в контексте урбанизации, можно сказать, что кабинетская аренда в Новониколаевске являлась одним из механизмов трансформации сельского населения в городское и осуществления «урбанизационного перехода» ${ }^{2}$.

В существующей историографической традиции кабинетское землевладение характеризуется исключительно как негативный фактор в истории Новониколаевска. Как пишут авторы обобщающей работы, оно являлось препятствием для заселения и землеустройства, якобы в итоге проведенного для города неудачно ${ }^{3}$. Такая же негативная позиция сложилась и в частности по вопросу земельно-арендных отношений. Она сводится к тому, что аренда была непомерно тяжела и тормозила торгово-промышленное развитие Новониколаевска ${ }^{4}$.

Однако при ближайшем изучении историографии оказывается, что специальных исследований земельно-арендных отношений между Новониколаевском и Кабинетом нет. К этому вопросу, как базовому для понимания социально-экономического развития Новониколаевска, историки часто обращаются, исследуя другие темы. Так, Л.Н. Воробцова в своей монографии не раз приводит архивные данные по аренде промышленных участков для характеристики местного купечества, однако не пытается пересмотреть устоявшуюся оценку аренды 5 .

Вообще в распоряжении историков до сих пор крайне мало первоисточников по данной теме, так что существует путаница даже на уровне описания фактов. Один из авторов сообщает, что «в 1893 г. стоимость аренды за кв. сажень составила 7 копеек, а в 1910 г. 80 копеек». ${ }^{6}$ Но известно, что к 1910 г. арендные отношения Кабинета ЕИВ и города были прекращены, и город уже выплачивал выкуп. Другой исследователь, рассматривая «влияние арендных отношений на формирование селитебной территории», приводит известный факт, что сначала арендаторы поселка платили Кабинету 1 рубль за усадьбу в год, но в этом же параграфе, ссылаясь на справочник Литвинова, пишет, что «к 1898 г. цены на усадебные участки выросли в среднем до 961 руб. в год» ${ }^{7}$. Между тем, в названном справочнике информация подана таким образом, что неясно, кем выставлена такая арендная плата Кабинетом или, например, субарендаторами, которые, судя по первоисточникам, в немалой степени формировали цены на аренду жилья и усадеб.

Эти примеры показывают, что земельно-арендная политика Кабинета в Новониколаевске изучена слабо, а источники по данной теме введены в научный оборот недостаточно. Между тем, делопроизводство Кабинета представляет собой достаточный корпус источников для изучения данного вопроса. Арендная документация отложилась в архиве как самого

\footnotetext{
1 Рындзюнский П.Г. Крестьяне и город в капиталистической России второй половины ХІХ века. М., «Наука», 1983. С.126-129.

${ }^{2}$ Сенявский А.С. Урбанизация России в ХХ веке: роль в историческом процессе. М., 2003. С. $36,37$.

${ }^{3}$ Скубневский В.А.. Гончаров Ю.М. Города Западной Сибири во 2-й половине XIX - начале XX веков: Население. Экономика. Застройка и благоустройство. Барнаул: «Аз Бука», 2007. С.55.

${ }^{4}$ Горюшкин Л.М., Бочанова Г.А., Цепляев Л.Н. Новосибирск в историческом прошлом: конец ХІХ - начало ХХ в. Новосибирск: Наука, 1978. С. 55, 56.

${ }^{5}$ Воробцова Л.Н. Частное предпринимательство в Новониколаевске (1893-1914) - Новосибирск: РИЦ НГУ, 2015. C.30.

6 Умбрашко К.Б. Чаус - Колывань - Новониколаевск: ирония судьбы. Источниковедческий аспект./ Освоение и развитие Западной Сибири в XVI-XX вв. Материалы межрегиональной научно-практической конференции, посвященной 300-летию Чаусского острога. - Новосибирск: Агентство «Сибпринт», 2013. С. 109-110.

${ }^{7}$ С.М. Новокшонов. Градостроительное развитие города Ново-Николаевска (Новосибирска) с 1893 по 1917 годы. - ГАУ НСО НПЦ, 2013 г. С. $39-40$.
} 
Кабинета, так и в его региональных представительствах - Главном управлении Алтайского округа и в Томском имении, поэтому комплексы источников представлены в фондах РГИА и ГААК, причем более детальной и разнообразной является арендная документация Алтайского округа.

Справедливости ради отметим, что начало критической оценки кабинетского землевладения в Новониколаевске было положено еще современниками. В 1903 г. газета «Сибирская жизнь» писала: «В земельном отношении положение Новониколаевска весьма не устойчиво, что не могло не оказывать задерживающего влияния на его рост и развитие торговли: поселок не имеет вовсе своей земли, те же земли, какими пользуются его жители, арендуются у Главного Управления Алтайского округа. Аренда краткосрочная, участки сдаются с торгов, вследствие чего в более оживленной части поселка арендные цены на усадебные места быстро возрастали. Отсутствие своей земли лишило поселок источников, из которых могли бы черпаться средства на так называемое городское благоустройство, не позволяло многим прочно обстраиваться» ${ }^{1}$. Далее выражается уверенность, что при условии выкупа земель темпы роста города обязательно возрастут. Арендная политика Кабинета неоднократно оказывалась под прицелом томской губернской прессы, но критиковались не «высокие» ставки аренды, а суть и экономические последствия арендного положения ${ }^{2}$.

Для анализа арендной политики Кабинета важно определить арендный период. Установление аренды особенно важно, так как оно означало узаконение нового поселка на кабинетской земле. В администрации Алтайского округа придавали этому большое значение: именно 1894 год, когда началась раздача участков в аренду, назывался временем возникновения поселка. Так, в 1902 г. управляющий Томским имением в рапорте начальнику округа сообщал: «23 июня 1894 г. последовало распоряжение начальника Алтайского округа Болдырева принять немедленно меры к полному упорядочению этого поселения, к выработке проекта будущего поселка с распланировкой местности, <..> каковое распоряжение и было приведено в исполнение в том же году. Осенью 1894 г. <..> роздано в аренду разным лицам усадеб по правую сторону Каменки - 385 и кроме того, 14 торговых помещений. Таким образом, основание нынешнего поселка следует отнести к осени 1894 года, т.е. к тому времени, когда Главным управлением Алтайского округа санкционировано было образование поселка и распланировано место для него».

Установление в поселке арендной платы за пользование землей было неотъемлемой частью землеустройства, основные события и итоги которого были изложены ранее 4 , а в данном случае важно определить административные последствия первоначального землеустройства и введения арендного землепользования. В этом отношении аренда земли стала для Новониколаевского поселка не только бременем, но и актом признания его законности как нового поселения, возникшего на землях Кабинета. Таким образом, в административно-хозяйственном отношении до получения городского статуса Новониколаевский поселок являлся ничем иным, как арендным поселком Алтайского округа - по выражению того времени - «арендной статьей» округа. В источниках существует немало прямых указаний на такой статус. В 1901 г. налоговый пристав писал, что «в 1897 г. поселок еще числился не выделенным из общих арендных статей» ${ }^{5}$, а в 1902 г. управляющий Томским имением прямолинейно назвал поселок «собственностью Кабинета Его Величества» ${ }^{6}$. На рубеже XIX-XX вв. в Алтайском округе на кабинетской земле было немало арендных поселков сельского типа, появившихся в результате активной крестьянской колонизации. Проблематика образования этих поселков, в том числе их арендные отношения

\footnotetext{
${ }^{1}$ Иллюстрированное приложение XV к газете «Сибирская жизнь». 1903, 10 августа. №173. С. 4.

${ }^{2}$ Сибирская жизнь. 1898, № 122. С.2. Сибирская жизнь. 1901. №180. С.2.

${ }^{3}$ Государственный архив Алтайского края (далее - ГААК). Ф.4. Оп. 1. Д.81. Л. 139 - 141.

${ }^{4}$ Минина Н.А. Образование города Новониколаевска: землеустройство в 1893-1895 гг./ Вестник Томского государственного университета. 2015. № 397. С. 147-153.

${ }_{5}^{5}$ Государственный архив Томской области (далее - ГАТО). Ф.196. Оп.1. Д.366. Л.8.

${ }^{6}$ ГААК. Ф. 4. ОП.1. Д.81. Л.145.
} 
с Кабинетом, разработана алтайскими историками ${ }^{1}$. На наш взгляд, Новониколаевск по сути арендного землепользования в догородской период равнозначен этим поселкам, но и отличался от них: он был единственным на территории Алтайского округа арендным поселком, чье развитие с самого начала имело исключительно торгово-промышленный, городской характер, в связи с чем земельно-арендные отношения Новониколаевска и Кабинета имели свою специфику.

Нужно отметить, что в историографии арендное положение Новониколаевского поселка трактовалось очень своеобразно. Авторы монографии «Новосибирск в историческом прошлом», назвав земельную собственность короны «крупным пережитком феодализма», отмечали, что земли, «находившиеся в непосредственном владении Кабинета, могли использоваться лишь за арендную плату», и здесь же привели данные: в 1893 г. цена аренды участка в поселке составляла 1 рубль ${ }^{2}$. Далее оценка арендного положения поселка приняла противоречивую форму: несмотря на приведенные выше факты, историки пришли к выводу, что он был незаконным, не имел «официального статуса». На наш взгляд, этот вывод был продиктован идеологическими соображениями, и по инерции транслируется в современных исследованиях.

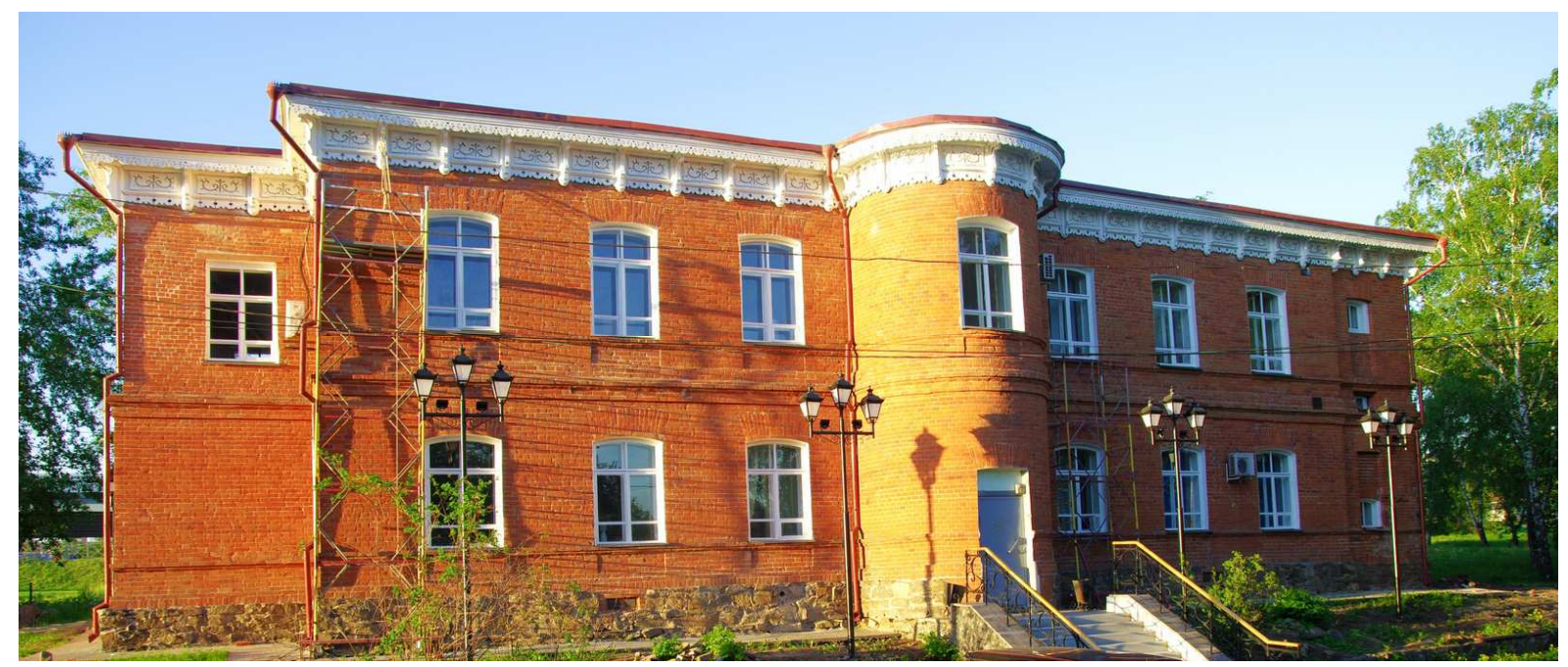

Здание канцелярии управляющего Томским имением Алтайского округа Кабинета Его Величества - единственное из сохранившихся зданий квартала № 1 Закаменской части Новониколаевска, почти полностью принадлежавшего Кабинету. Здание построено в 1899-1900 г. по проекту, составленному в Санкт-Петербурге, в Кабинете Его Величества. Современный адрес: ул. Обская, 4.

Итак, арендные платежи были введены в поселке весной-летом 1894 года. Первоначально аренду взимали чиновник по сбору аренды и местный лесничий ${ }^{3}$, в в первой половине 1896 г. все арендные дела перешли в ведение управляющего Томским имением. Должности управляющих имениями Алтайского округа были введены указом 11 апреля 1896 г. и ликвидированы вместе с имениями в 1911 г. Управляющий подчинялся непосредственно начальнику Алтайского округа, ведал охраной и эксплуатацией лесов, организацией сдачи в аренду и отводом земельных участков ${ }^{4}$. Размещение администрации Томского имения в Новониколаевском поселке не было случайностью - к этому времени поселок представлял

\footnotetext{
${ }^{1}$ Кухаренко А.Е. Дореволюционная и советская историография земельно-арендной политики Кабинета в Алтайском (горном) округе/ Известия Алтайского государственного университета. Серия: История, политология. - 2012. - № 4/2. С. 146 - 150; Храмков А.А. Арендные поселки в Алтайском округе в нач. ХХ в. // Барнаулу 250 лет. Барнаул, 1980. С.138 - 141.

${ }^{2}$ Горюшкин Л.М., Бочанова Г.А., Цепляев Л.Н. Новосибирск в историческом прошлом: конец ХІХ - начало ХХ в. Новосибирск: Наука, 1978. С. 55, 56.

${ }^{3}$ ГААК. Ф. 3. Оп.1. Д.913. Л.46.

${ }^{4} \mathrm{http}$ //guides.eastview.com/browse/guidebook.html?bid=56\&sid=370586
} 
собой очень неспокойное и прибыльное арендное хозяйство, которое требовало постоянного присутствия. В июле 1898 г. управляющий Кабинетом П.К. Гудим-Левкович распорядился построить в поселке не деревянное, как предполагалось сначала, а кирпичное здание для канцелярии Томского имения ${ }^{1}$.

Для проведения объективного анализа аренды необходимо классифицировать ее по видам хозяйственной деятельности. Как следует из финансовых документов Главного управления Алтайского округа, арендная плата в Новониколаевске взималась дифференцированно за следующие группы земель: 1) жилые усадьбы; 2) участки для торгово-промышленных заведений в селитебной части города; 3) оброчные (арендные) статьи для устройства промышленных предприятий².

Политика Кабинета в отношении аренды жилых усадеб претерпела серьезные изменения. Как только поселок в 1894 г. получил свой первый план, с занятых участков вновь поселившиеся должны были платить 1 руб. в год за жилую усадьбу в 250 кв. сажен - такая ставка была предусмотрена в целом по Алтайскому округу ${ }^{3}$, но, учитывая выгодное положение нового поселка, арендная плата повышалась в зависимости от спроса на усадьбы. 10 июня 1897 г. управляющим Томским имением была представлена в Главное управление Алтайского округа сводная ведомость всех арендаторов Новониколаевского поселка 4 . Эта ведомость входила в пакет документов о состоянии поселка, затребованный Кабинетом после получения телеграммы жителей на имя царя с просьбой «переименовать» поселок в город или посад. На основании этих документов должна была решиться судьба молодого населенного пункта 5 .

По данным ведомости, к лету 1897 г. были сданы 1229 усадеб по цене от 1 до 5 руб., в зависимости от положения усадьбы, причем подавляющее большинство усадеб сданы по 1 рублю. Торги устраивались на те усадьбы, которые пользовались повышенным спросом - в основном это участки, выходящие на базарные площади либо участки, удобные для размещения торговых лавок и других коммерческих объектов. Дешевая аренда жилых усадеб сохранялась с момента ее введения в 1894 г. в течение нескольких лет и стимулировала активный рост населения поселка. Однако в арендном процессе были свои нюансы: судя по делопроизводственной переписке Главного управления Алтайского округа, ведомство оказалось не готово к заключению арендных договоров с жителями поселка - первоначально отсутствовала сама форма договора.

Весной 1894 г. в качестве образца для заключения арендных договоров с разночинцами, поселившимися в бору у Каменки, чиновник по сбору аренды предложил форму платежного свидетельства, заключаемого с жителями заводских поселков: «арендаторы будущих усадеб домогаются узнать правила и условия аренды. Представляя при сем бланк платежного свидетельства, предназначавшийся для выдачи усадеб на правах аренды в заводских селениях, не найдет ли Земельная часть нужным сделать распоряжение отпечатать таковые к руководству, изменив и дополнив редакцию» ${ }^{6}$. Неизвестно, было ли данное «свидетельство» использовано для выработки договоров для Новониколаевского поселка, но выявленные договоры (назывались они обычно «условия») на аренду жилых усадеб позволяют сравнить договорные положения в горнозаводских поселках и в Новониколаевском. Самый ранний из выявленных договоров, заключенных с новониколаевцами, датирован 23 января 1896 г., а сравнение его с другими, более поздними договорами, говорит о том, что это - типовой договор ${ }^{7}$.

\footnotetext{
${ }^{1}$ Российский государственный исторический архив (далее - РГИА). Ф. 468. Оп.27. д.440. Л.5, об.

2 Кроме того, сдавались в аренду весы и торговые места на базарах и т.д., но это не относится к земельной аренде и потому не рассматривается в настоящей статье.

${ }^{3}$ ГААК. Ф. 3. Оп.1. Д.913. Л.16.

${ }^{4}$ ГААК. Ф. 4. ОП.1. Д.81. Л. $52-83$.

${ }^{5}$ ГААК. Ф. 4. Оп.1. Д.81. Л. 23.

${ }^{6}$ ГААК. Ф. 3. Оп. 1. Д.913. Л.59-60.

${ }^{7}$ ГААК. Ф. 146. ОП.1.Д.18. Л.43, об.
} 
Договор для заводских поселений не был равноправным: так, если усадьба понадобится собственнику (Кабинету), то «все находящиеся на нем постройки должны быть по требованию немедленно снесены на счет владельца этих построек», а если «начальством будут изменены условия аренды, то им беспрекословно подчиняться или очистить на свой счет занимаемое место». В договоре для поселка такая ситуация также предусматривалась, но с оговоркой, что если участок «может понадобиться Главному управлению, но только не для сдачи в аренду другим лицам», то арендатор должен освободить в 6-месячный срок, за свой счет. Случаев применения таких драконовских мер против жителей в делопроизводстве не встречено - единственным основанием для расторжения договора со всеми вытекающими последствиями являлся 3-месячный срок неоплаты. В договоре 1896 года допускалась передача арендатором участка в другие руки, но с разрешения окружной администрации или арендного чиновника; взыскание недоимок по аренде происходило в административном порядке, то есть, через полицию, а все споры арендатор мог решить в суде.

Отметим, что и позже возникали ситуации, когда «формальных» договоров не было. Например, в июне 1897 г. управляющий Шубенко сообщал, что «не на все усадьбы заключены условия и впредь до выяснения положения поселка относительно его устройства прекращено заключение условий», поэтому условия заключались «устно» с ведением специальных списков и ведомостей ${ }^{1}$.

В 1897 г. начался новый этап земельно-арендных отношений. 13 ноября 1897 г. последовало повеление Николая II о преждевременности преобразования поселка в город и отнесении расходов по благоустройству на Кабинет до тех пор, пока выяснятся «значение поселка и виды на его будущее» ${ }^{2}$. То есть, содержание полиции, проведение благоустройства и другие расходы, которые обычно несет местное самоуправление, возлагались на Кабинет.

С целью упорядочения Кабинет внес некоторые изменения в арендную систему. Арендаторы должны были в обязательном порядке заключать арендный договор, а заключенные ранее договоры оставались в силе. Арендная ставка рассчитывалась от квадратной сажени, а не от всего участка, причем стоимость ее была увеличена и составила от 1 до 2,5 копейки, соответственно 2,5 - 5 руб. за усадьбу. Разрешалось дробить усадьбу, если для застройщика она окажется большой. ${ }^{3}$ Кабинет в своем распоряжении приветствовал заключение долгосрочных договоров - на 24-36 лет, а «при обязательстве возвести особо ценные постройки - и на более продолжительный срок». Выявленная арендная документация показывает, что договоры на 24 года заключались на участки торгово-промышленного назначения, а на жилые и торговые усадьбы заключались договоры краткосрочные, на 12 лет $^{4}$. Например, Н.П. Литвинов в 1899 г., взяв с торгов участок, прилегающий к Новой Базарной площади, вскоре отказался от заключения договора ввиду короткого 12-летнего срока при высокой стоимости - 200 р. 30 коп. в год 5 . В фондах Новосибирского государственного краеведческого музея хранится договор, заключенный Главным управлением Алтайского округа с запасным ефрейтором Федором Ковальчуком - мужем известной подпольщицы Дуси Ковальчук. Договор был заключен 3 августа 1898 г. сроком на 10 лет, с платой 1 руб. в год․ В архивном фонде Кабинета выявлен список из 27 арендаторов, желавших заключить договоры аренды жилых усадеб на срок более 24 лет, причем ставки, согласованные с Алтайским округом, составляли 3 - 10 руб. в год. Кабинет эти договоры не утвердил по выше приведенной причине, указав при этом начальнику округа на его управленческую ошибку ${ }^{7}$. Таким образом, фактически с жителями на обычные усадебные участки заключались только срочные договоры.

\footnotetext{
${ }^{1}$ РГИА. Ф. 468. Оп.27. Д.595. Л.5.

${ }^{2}$ ГААК. Ф. 4. ОП.1.Д.81. Л.89- 91 об

${ }^{3}$ ГААК. Ф. 4. ОП. 1. Д.81.Л. 90.

${ }^{4}$ РГИА. Ф. 468. Оп.27. Д.440. Л.42.

${ }^{5}$ ГААК. Ф. 4. Оп.1. Д.2464. Л.297.

${ }^{6}$ НГКМ. ОФ-11915.

${ }^{7}$ РГИА. Ф. 468. Оп.27. Д.440. Л. 25-26, 86, об.
} 


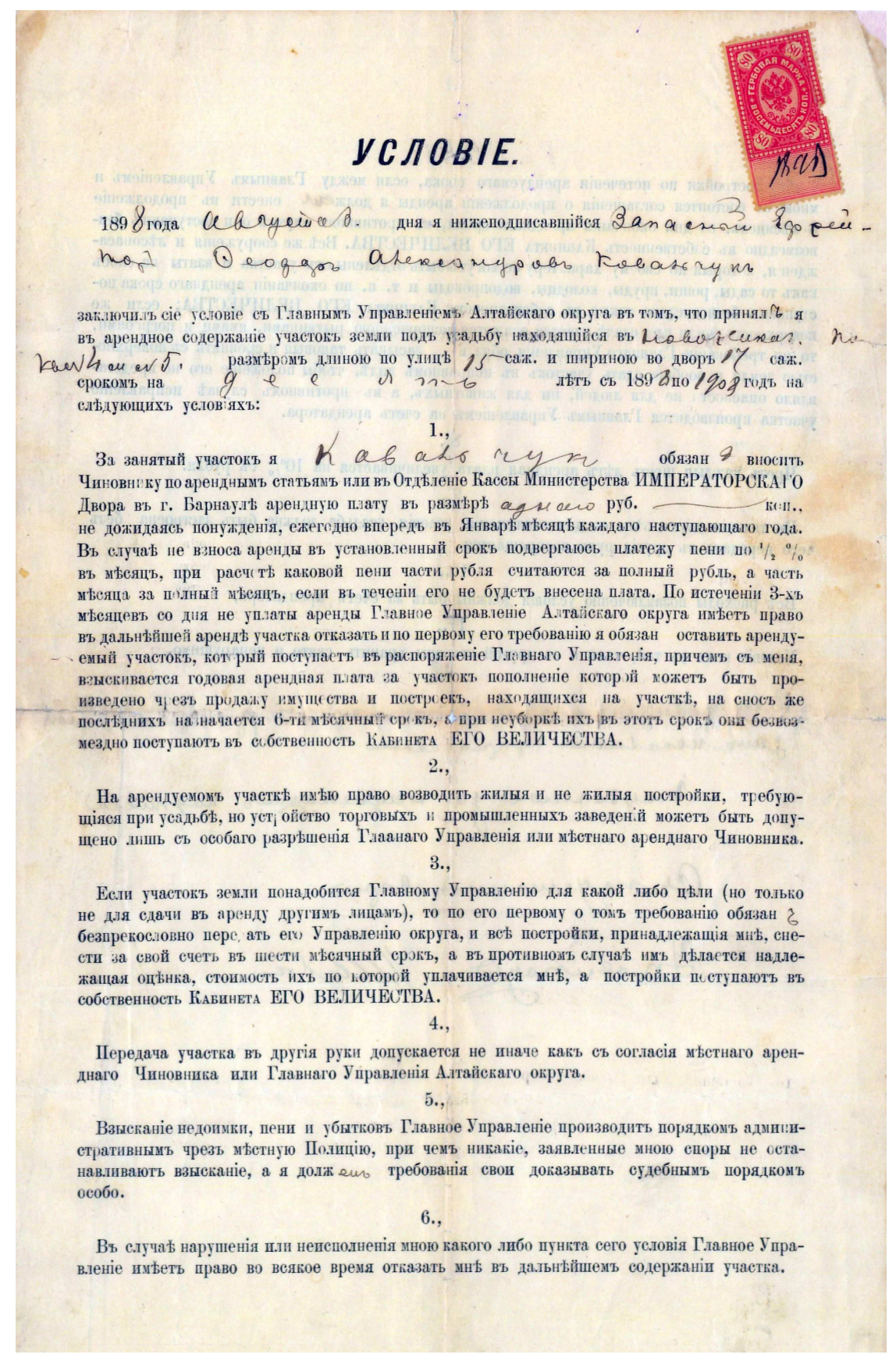

Договор аренды («условие») Федора Александровича Ковальчука на участок № 5 в Вокзальной части Новониколаевского поселка, в квартале № 4. Цена договора - 1 рубль в год, срок - десять лет, с

1898 г. по 1908 г. В 1904 г. на этом участке построен жилой дом, сейчас это памятник истории жилой дом Евдокии Ковальчук (жены Ф.А. Ковальчука), члена большевистского подполья во время Гражданской войны (ул. Ленина, 82).

Из фондов Новосибирского государственного краеведческого музея

В связи с повелением от 13 ноября, изменения в расценках на жилые усадьбы заметны уже в данных лета 1898 года: в Вокзальной части участки в кварталах, расположенных близко к вокзалу станции Обь (№ 1, 2, 16, 17), в которых велась торговля, открывались постоялые дворы и гостиницы, сдавались по 7,5 - 10 руб.; в кв. № 3 и 4-7,5 - 5 руб.; № 5-11 по 5 р., а начиная с кв. № $12-4$ р. за усадьбу, то есть, чем дальше вглубь района, тем дешевле аренда. В этих же пределах были расценки на усадьбы в Центральной и Закаменской частях, хотя в Закаменке земля традиционно была самой дешевой: с 12 по 34 
квартал аренда участков составляла 2,5 руб. В Центральной и Вокзальной частях тоже были участки по 2,5 руб., но их было немного ${ }^{1}$.

Оценить реальные ставки кабинетской аренды можно по данным о стоимости аренды готового жилья. В 1899 г. полицейский пристав Иван Капени жаловался, что аренда дома под полицейское управление с имеющимися в нем жилыми комнатами обошлась ему в 360 руб. за год². Из делопроизводства Кабинета и Алтайского округа видно, что сдача в аренду жилья в поселке была распространенным видом предпринимательства первых домовладельцев. Показателен случай колыванского купца 2 гильдии Абрама Островского, который просил Алтайский округ снизить ему аренду усадьбы на улице Вознесенской, примыкающей к Базарной площади. Управляющий Соболев решил оставить прошение Островского «без последствий», в связи с тем, что тот «арендовал участок с торгов за 144 р. сроком до 1905 г., на участке построил дом под торговое помещение, в нем живет портной Кандюрин, который платит Островскому 180 р. в год». По ведомости 1897 г. удалось выяснить, что «первый староста города» Илья Титлянов арендовал в поселке шесть участков; бывший колыванский мещанин, постоянный застрельщик разных ходатайств Ефим Шапкин - целых девять; Н.П. Литвинов - два, а Евграф Жернаков - десять участков, хотя сам купец не жил в Новониколаевском поселке ни дня ${ }^{3}$. Этот ряд можно продолжать, но совершенно очевидно, что арендаторы нескольких участков получали с них дополнительный доход, существенно влияя на цены готового жилья и участков, сдаваемых в субаренду. При всем этом нужно отметить, что Титлянов и Шапкин писали ходатайства в Кабинет и представителям монаршего дома о снижении аренды на свои усадьбы до 1 руб., с обвинениями окружной администрации в притеснениях ${ }^{4}$. Вообще новониколаевцы не стеснялись просить Кабинет (а в некоторых случаях и царя) о различных уступках, в том числе по части арендной платы. Выше было сказано, что первоначально, когда участки сдавались по 1 руб. в год, договоры не заключались по вине окружной администрации - еще не была готова форма арендных договоров, но тем арендаторам, кто хотел заключить эти договоры, велся учет. В 1898 г. проезжавшему через поселок управляющему Кабинетом П.К. Гудим-Левковичу была подана коллективная петиция о возвращении всем, кто заявлял управляющему имением о своей готовности заключить договор, прежней арендной ставки в 1 рубль. Гудим-Левкович посчитал прошение справедливым и попросил жителей составить именной список. Список оказался подозрительно обширным - 327 человек ${ }^{5}$.

С течением времени арендные ставки на жилые усадьбы стали отличаться неравномерностью - все зависело от времени заключения договора, поэтому первые жители поселка оказались в лучших условиях, чем поселившиеся позже, а разница арендных ставок могла быть десятикратной. Вполне возможно, что те цифры, которые приводятся в публикациях как ставки кабинетской аренды, являются в действительности арендной платой, установленной самими жителями, сдававшими участки в субаренду. Это подтверждается данными о расценках на жилые усадьбы, сданные с торгов. Так, житель Новониколаевска Кононов в 1905 г. взял с торгов участок земли на Журинской улице в квартале № 100 за 80 руб. 50 коп. в год, внес аренду только за 1-е полугодие, а далее от оплаты уклонялся. В 1907 г. он получил участок на выкуп, но арендный долг оплатить отказывался, задолжав Кабинету вместе с пеней 130 р. 12 коп. Вместо оплаты долга он написал заявление на имя монарха о сложении с него недоимки, но Кабинет оставил его просьбу «без последствий» 6 . Важно зафиксировать стоимость аренды с торгов: 80 рублей - относительно дорого, но все же это не сумма в 961 руб., что указана в справочнике Н.П. Литвинова и повторяется в упомянутых выше работах исследователей. Столь высокие ставки аренды не могли выходить

\footnotetext{
${ }^{1}$ РГИА. Ф. 468. Оп.27. Д.440. Л.27-32.

2 РГИА. Ф. 468. ОП.27. Д.440. Л.14-16 об.

${ }^{3}$ ГААК. Ф. 4. ОП. 1. Д.81. Л. $50-81$.

${ }^{4}$ РГИА. Ф. 468. Оп. 27. Д. 440. Л.162-16 3об.; Д. 595. Л.2 - 4 об.

5 ГААК. Ф. 4. Оп.1. Д.2464. Л. $275-278$.

${ }^{6}$ РГИА. Ф. 468. Оп.27. Д.439. Л.141,
} 
за рамки единичных исключений, иначе доходы Кабинета от аренды были бы в разы выше, чем мы видим по данным управляющего Томским имением: в 1897 г. валовый доход Кабинета в поселке составил 15634 руб., в 1898 г. - 23128 руб., 1899 г. - 28463 руб., 1900 г. 34601 руб., 1901 г. - 39649 руб. ${ }^{7}$ По сведениям управляющего Томским имением, к 1902 г. в поселке было сдано 2646 участков ${ }^{8}$.

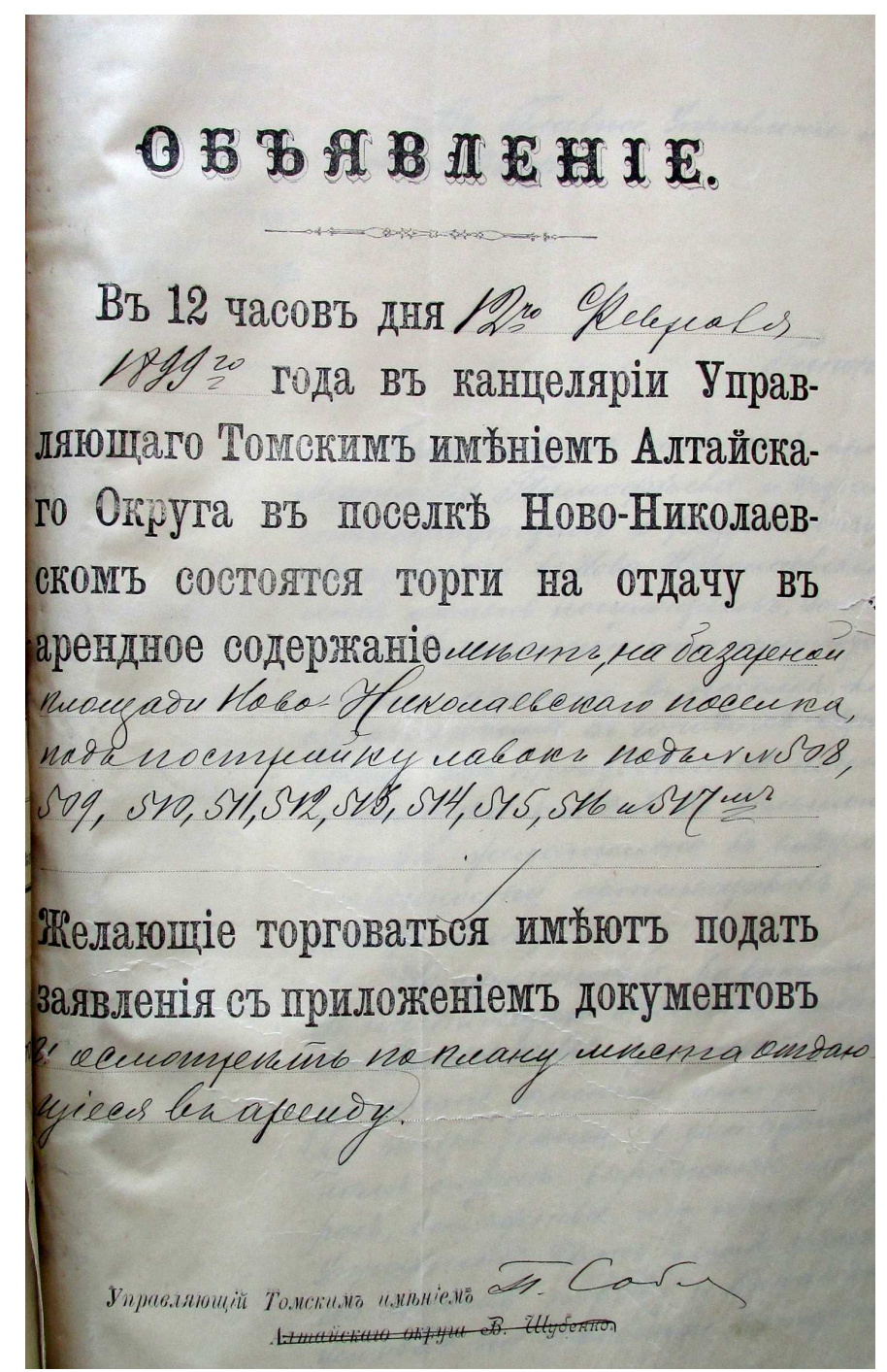

Фото 3. Объявление о проведении торгов на аренду мест на базарной площади.

Новониколаевск, 1899 г. ГААК. Ф.4. Оп.1. Д.2464. Л.15.

Резкий рост стоимости кабинетской аренды начался с 1903 г. и был связан с подготовкой к выкупной сделке. Позже в своих воспоминаниях Н.П. Литвинов свидетельствовал, что Алтайский округ «раздавал участки направо и налево», развивая среди жителей ажиотаж, чтобы «поднять выкупную сумму» ${ }^{9}$. Управляющий А.Г. Киюц сообщал, что «до 1902 г. включительно усадьбы сдавались без торгов, по оценке от 1 до 5 руб. <..> затем, когда потребность в участках выросла в связи с увеличением населения, участки сдавались с торгов: в 1903 г. сдано 161 участок, в 1904 г. - 166, в 1905 г. - 146. Такое небольшое количество предъявляемых к торгам участков не могло удовлетворить нуждающихся в них; с

\footnotetext{
${ }^{7}$ ГААК. Ф. 4. ОП.1. Д.81. Л.141.

${ }^{8}$ РГИА. Ф. 468. Оп.27. Д.439. Л.38.

${ }^{9}$ HOКМ. ОФ-17417/1.
} 
целью же поднять цену на переуступку арендных прав на арендованные раньше участки явились спекулянты, которые, поднимая цену на торгах до баснословных размеров (в 1903 г. до 95 руб. за участок, в 1904 г. - 130 и в 1905 году - 505 руб. 50 к.), скупали до 10-15-20 участков в одни руки. Само собой разумеется, что для рабочих, служащих взять участок при таких ценах было немыслимо» ${ }^{10}$. Собственно, Кабинет, выставляя на торги сравнительно небольшое количество участков, преследовал коммерческую выгоду: судя по плану НовоНиколаевска 1906 г., на котором начертано более 350 кварталов, в наличии у Кабинета было порядка 7 тыс. участков (вместе с уже заселенными), то есть, резерв свободной земли имелся.

Из-за того, что Кабинет преследовал сугубо коммерческие интересы, в 1906 г. в городе сложилась взрывоопасная ситуация, и Кабинет был вынужден передать нуждающимся горожанам свободные участки без торгов, практически по расценкам 1897-1898 гг. Однако всех удовлетворить не получилось: управляющий назначил к сдаче 1638 свободных участков, а подано было 4200 заявлений ${ }^{11}$. В этой ситуации были выставлены ограничения для заявителей: состав семьи не менее 4-х человек, проживание в Новониколаевске не менее одного года и отсутствие у заявителя усадеб. Обеспеченность собственным жильем (земельными участками) по данным однодневной переписи 1905 г. была следующая: в городе было 5397 домовладельцев (муж. пола) и 6182 арендаторов (муж. пола), а также около тысячи человек жили при промышленных предприятиях ${ }^{12}$.

Негативным следствием коммерциализации кабинетской аренды стал самовольный захват земли в черте города (на территории переселенческого пункта, возле складов «Нобель») и образование второго самовольного поселения, получившего название «Малая Нахаловка», или «Порт-Артур». По данным управляющего Томским имением, первоначально здесь заселилось 50 человек $^{13}$, были приняты меры по их выселению силами полиции, но безуспешно: самовольщики настаивали на праве жить за чертой города бесплатно и отправили жалобу в столицу на действия полиции и окружной власти. Объясняя ситуацию перед Кабинетом, начальник Алтайского округа писал, что самовольщики могли бы при желании поселиться в городе - Алтайский округ выставил минимальные цены на участки, но среди самовольщиков «много шпаны, т.е. людей, этика которых расходится с понятиями о совести, законности и культуре...» ${ }^{14}$ Нахаловку не удалось ликвидировать и городскому самоуправлению: в 1914 г. в ней проживало уже 82 семьи. Показательно, что это были исключительно крестьяне, причем подавляющая часть - из Европейской России ${ }^{15}$.

В арендной деятельности Кабинета была и другая, весьма отличная от рассмотренных фактов, практика: льготная аренда жилых участков. Например, отставные солдаты по закону имели право на бесплатное занятие участка в черте городов империи - это правило действовало и в Новониколаевске ${ }^{16}$. На льготных условиях (без торгов, по оценочной стоимости) были предоставлены в 1900 г. усадьбы для 106-ти железнодорожников, при переводе их со ст. Кривощеково на ст. Обь, в связи с объединением железных дорог ${ }^{17}$.

Сказанное выше касалось сдачи в аренду жилых участков. Другим видом аренды были оброчные (арендные) статьи для устройства промышленных предприятий. В отношении промышленной аренды еще в 1897 г. Кабинет распорядился «на первое время поощрять открытие торговых и промышленных заведений и не обременять предпринимателей особыми платежами». Данная политика просматривается в арендных ведомостях: в окрестностях Новониколаевска сдавались земли для торгово-промышленных целей и

\footnotetext{
${ }^{10}$ РГИА. Ф. 468. Оп.27. Д.439. Л.38.

${ }^{11}$ РГИА. Ф. 468. Оп.27. Д.439. Л.35-37 об.

${ }^{12}$ ГАТО. Ф. 200. Оп.1. Д. 11. Л.91.

${ }^{13}$ РГИА. Ф. 468. Оп.27. Д.439. Л.57-62.

${ }^{14}$ РГИА. Ф. 468. Оп.27. Д.439. Л.60.

${ }^{15}$ ГААК. Ф. 4.Оп. 1. Д.3601. Л.4 - 19 об.

${ }^{16}$ ГАНО. Ф. Д-97. ОП.1. Д.66. Л.94- 95 об.

${ }^{17}$ ГААК. Ф. 146. Оп.1. Д.6. Л.8- 11.
} 
других нужд, аренда за земли была дифференцированной в зависимости от типа и размера предприятия. В пойме Каменки в короткий срок сформировалась старейшая городская промзона: здесь работали водяные мельницы, частные маслодельные и кирпичные заводы («кирпичные сараи»). Стоимость аренды была невысокой: за участки под мельницы и кирпичные заводы - 12-16 руб. в год ${ }^{1}$. В пойме Каменки и Малой Ельцовки разбивались огороды, сенокосы и пасеки, аренда которых была несущественной. Сравнительно дорогой была аренда участков для каменоломен - не менее 100 руб. в год².

Арендные ставки на промышленные земли в районе Новониколаевска были достаточно велики. Учитывая благоприятные естественно-географические условия Новониколаевска, кабинетское ведомство целенаправленно выделило территории между Обью и селитебной частью города для сдачи их в аренду под промышленные предприятия. В 1903 г. были подготовлены участки в местности «Сосновая дача» (или «Сосновская дача», в дальнейшем эта местность стала улицей Фабричной), которая являлась наиболее выгодной для размещения предприятий. В 1904 г. началась сдача участков с торгов. В объявлении о торгах на первые участки (№2 и 3) в «Сосновой даче» размером почти 1,5 дес., указывалась стартовая цена в 20 коп. за кв. сажень. Участок № 1 и 2 взял в аренду Александр Луканин, причем уч. № 2 перешел затем «Алтайской фабричнопромышленной компании» (АФПК). Проследить цены на промышленные участки позволяет «Список арендных оброчных статей по берегу р. Оби от железнодорожного моста до р. Ельцовки», составленный управляющим Томским имением в 1905 г. ${ }^{3}$

\begin{tabular}{|c|c|c|c|}
\hline Арендатор и срок аренды & $\begin{array}{l}\text { Количество земли, } \\
\text { (десятин, кв. сажс.) }\end{array}$ & $\begin{array}{c}\text { Сумма аренды } \\
\text { (руб, коп.) }\end{array}$ & $\begin{array}{c}\text { Средняя } \\
\text { стоимость за } \\
\text { кв. саж. }{ }^{4}\end{array}$ \\
\hline $\begin{array}{l}\text { Пристань пароходства } \\
\text { Богословского горного } \\
\text { округа, 1898-1910 гг. }\end{array}$ & 2 дес. 1200 & 1352,98 & ок. 17 коп. \\
\hline $\begin{array}{l}\text { Постройки 9-го участка } \\
\text { Сибирской жел. дороги, } \\
\text { 1898-1910 гг. }\end{array}$ & 1 дес. 2276 & 701,40 & ок. 12 коп. \\
\hline $\begin{array}{l}\text { А.М. Луканин (Сосновая } \\
\text { оброчная статья, уч. № 1), } \\
\text { 1905-1929 г. }\end{array}$ & 2 дес. 56 & 1456,80 & 22 коп. \\
\hline $\begin{array}{l}\text { АФПК (Сосновая оброчная } \\
\text { статья, уч. № 2-6, 9,17), } \\
\text { 1905-1929 гг. }\end{array}$ & 7 дес. 2200 & 4595,75 & ок. 19 коп. \\
\hline $\begin{array}{l}\text { Общество «Мазут» } \\
\text { Керосиновый склад, 1901- } \\
1925 \text { гг. }\end{array}$ & 2 дес. & 800,0 & 12,5 коп. \\
\hline $\begin{array}{l}\text { Керосиновый склад } \\
\text { Т-ва «Нобель», 1897-1917 гг. }\end{array}$ & 3 дес. & 550,0 & 6 коп. \\
\hline $\begin{array}{l}\text { Ново-Николаевское } \\
\text { мукомольное товарищество» }\end{array}$ & 5 дес. 1408 & 770,0 & 4,5 коп. \\
\hline Переселенческий пункт & 20 дес. 750 & - & \\
\hline
\end{tabular}

\footnotetext{
${ }^{1}$ ГААК. Ф.4. Оп.1. Д.81. Л.217- 287.

${ }^{2}$ ГААК. Ф.146. Оп.1. Д.1. Л. 1-102.

${ }^{3}$ ГААК. Ф.4. Оп.1. Д.2646. Л. 118.

${ }^{4}$ Вычислено автором.
} 
Политику Кабинета в отношении промышленной земельной аренды можно оценить как достаточно эффективную: пустующих участков в пределах Новониколаевска практически не было, а крупные предприятия были основаны в городе еще в то время, когда земля принадлежала Кабинету. Как известно, в 1907 г. земли были переданы городу на выкуп, и сложилась парадоксальная ситуация: городское самоуправление, которое всегда жаловалось на тяжесть кабинетской аренды на промышленные земли, теперь, получив эти земли на выкуп, отнюдь не торопилось продавать их промышленникам-арендаторам, но продолжало сдавать промзону в аренду. Сохранилось немало жалоб промышленников на действия городского управления в окружную и губернскую администрацию, которые, впрочем, уже не вправе были регулировать внутригородские земельные отношения ${ }^{1}$.

Тем не менее, эффективность кабинетской земельной аренды в Новониколаевске ставилась под сомнение уже через несколько лет своего существования самими чиновниками. Так, в ноябре 1898 г. руководство Кабинета направило начальнику Алтайского округа распоряжение прислать сведения о состоянии поселка, так как «ввиду быстрого развития поселка и выясняющейся необходимости преобразования его в посад или город, имеется предположение <..> наделить его, наравне с прочими городами Округа, селитебными и выгонными землями на праве собственности, с дарованием ему прав городского поселения...» ${ }^{2}$. Это распоряжение поступило в ответ на очередное ходатайство начальника округа В.К. Болдырева о возведении поселка в статус города, но с сохранением арендного положения ${ }^{3}$. Таким образом, преобразование поселка в город и наделение его землей с сохранением или прекращением аренды - взаимосвязанные вопросы, их решение было очевидным для всех сторон, но погрязало в бюрократических процедурах.

К 1904 году, когда поселок уже стал городом, но аренду за усадьбы и промышленные территории по-прежнему платил, руководство Алтайского округа вполне понимало пагубность арендного положения. Помощник начальника округа А.В. Розанов считал, что «преобразование поселка в город при оставлении усадебных земель обывателям в долгосрочную аренду едва ли можно считать целесообразным и выгодным для ведомства Кабинета и жителей поселка», отмечая, что аренда будет неэффективна со всех сторон: нужна будет специальная арендная служба, возникнет трудность исчисления ставок аренды, а жителям останется непрочность финансового положения, особенно промышленникам. Будучи юристом, Розанов привел следующий аргумент: «по смыслу городового положения, обладание имущественным цензом, в виде недвижимой собственности, является необходимым условием для выбора лиц, ведающих городское хозяйство. Следовательно, устройство города на арендных условиях потребует специальных исключений закона» ${ }^{4}$.

В целом, Новониколаевск был арендатором кабинетских земель значительный период своей истории - с 1894 г. до 1 марта 1907 г., когда в связи с Высочайшим указом 18 февраля 1907 г. город получил усадебные земли и прирезок к выгону на выкуп, ${ }^{5}$ и с этого момента городские обыватели и муниципалитет превратились из арендаторов земли в ее собственников.

Тем не менее, необходимо конкретизировать время прекращения арендных отношений, так как собственником земли город становился поэтапно. С получением городского статуса по Высочайшему указу 28 декабря 1903 г. Новониколаевск получил земли общего пользования в количестве 4881 дес. 2260 саж. безвозмездно. В эти земли входили улицы, площади, набережные, кладбища, а также городской выгон. Выгон располагался на юговостоке города, за селитьбой Закаменской и Центральной частей. На выгонных землях

\footnotetext{
${ }^{1}$ ГАТО. Ф.3. Оп. 23. Д.32.

${ }^{2}$ ГААК. Ф.4. Оп.1. Д.81. Л.107.

${ }^{3}$ ГААК. Ф.4. Оп.1. Д.81. Л. 105-106

${ }^{4}$ ГААК. Ф.4. Оп.1. Д.81. Л. 298.

${ }^{5}$ ГАТО. Ф.3. Оп.23.Д.6. Л.222, об.
} 
находились предприятия (каменоломни, карьеры, мельницы, огороды), хозяева которых платили Кабинету аренду, а с 1904 г. аренда уплачивалась городу. Усадьбы горожан представляли собой другую категорию земель - по закону усадьбы могли передаваться из императорской в частную собственность лишь посредством выкупа, что и было подтверждено указом 1903 г. Однако выкупную сделку Кабинет задержал более чем на три года, и арендные платежи за усадьбы взимались вплоть до указа 18 февраля 1907 г. и были прекращены полностью 1 марта 1907 г.

Итак, почти 15 лет, большую часть своей дореволюционной истории, Новониколаевск являлся арендатором Кабинета, при этом к 1908 году насчитывал 50 тыс. жителей, несколько крупных и десятки мелких торгово-промышленных предприятий, которые также находились на арендованной у Кабинета земле. Размер арендной платы изначально был установлен Кабинетом на доступном для всех уровне. Но когда выяснилось, что земли быстро растущего поселения пользуются повышенным спросом, Кабинет перешёл к сдаче участков через торги, что привело к резкому росту арендных цен. Очевидно, что Кабинет таким путём боролся за повышение своих доходов за счёт горожан. Однако, вопреки существующей историографической традиции, нет оснований обвинять Кабинет в искусственном завышении цен, нет оснований называть арендную политику Кабинета грабительской.

Повышение арендной платы на жилые участки в поселке было обусловлено ростом населения и, соответственно, спроса на землю, иначе говоря, арендная политика подчинялась законам свободного рынка, когда спрос, определяемый самим населением, рождал и соответствующее предложение. Кабинет, проводя торги на усадебные участки (и ограничивая число выставляемых участков), умело использовал рычаги свободного рынка (что не мешало чиновникам называть нарождающуюся прослойку арендаторовдомовладельцев спекулянтами). Но в основе своей цены сдаваемых участков зависели не от произвола кабинетских чиновников, а от рыночной стихии. Таким образом, уровень арендных цен в Новониколаевске служит показателем не аппетитов Кабинета Его Величества, а скорости роста Новониколаевска, который даже в статусе посёлка, с первых лет существования, представлял особое явление в истории сибирских городов.

\section{Статья поступила в редакиџю 22.09.2018 г.}

\section{Лumepamypa}

Горюшкин Л.М., Бочанова Г.А., Л.Н. Цепляев. Новосибирск в историческом прошлом: конец XIX - нач. XX в. - Новосибирск, «Наука», 1978. - 293 с.

Градостроительство России середины XIX - начала XX века. Книга 1. Общая характеристика и теоретические проблемы. М., Прогресс-Традиция, 2001. - 340 с.

Воробцова Л.Н. Частное предпринимательство в Новониколаевске (1893-1914) Новосибирск: РИЦ НГУ, 2015. - 436 с.

Кухаренко А.Е. Дореволюционная и советская историография земельно-арендной политики Кабинета в Алтайском (горном) округе/ Известия Алтайского государственного университета. Серия: История, политология. - 2012. - №4/2. С. 146 - 150.

Минина Н.А. Образование города Новониколаевска: землеустройство в 1893-1895 гг./ Вестник Томского государственного университета. 2015. № 397. С. 147-153.

Новокшонов С.М. Градостроительное развитие города Ново-Николаевска (Новосибирска) с 1893 по 1917 годы. / под ред. Е.А. Кузнецовой. - ГАУ НСО НПЦ, 2013. - 148 с.

Рындзюнский П.Г. Крестьяне и город в капиталистической России второй половины ХІХ века. М., «Наука», 1983. - 268 с.

Сенявский А.С. Урбанизация России в XX веке: роль в историческом процессе. М., 2003. $-286 \mathrm{c}$. 
Скубневский В.А.. Гончаров Ю.М. Города Западной Сибири во 2-й половине XIX начале XX веков: Население. Экономика. Застройка и благоустройство. Барнаул: «Аз Бука», 2007. -252 c.

Умбрашко К.Б. Чаус - Колывань - Новониколаевск: ирония судьбы. Источниковедческий аспект. / Освоение и развитие Западной Сибири в XVI-XX вв. Материалы межрегиональной научно-практической конференции, посвященной 300-летию Чаусского острога. Новосибирск: Агентство «Сибпринт», 2013. С. 109 - 110.

Храмков А.А. Арендные поселки в Алтайском округе в нач. XX в. // Барнаулу - 250 лет. Барнаул, 1980. С. $138-141$.

\section{References}

Goryushkin L.M., Bochanova G.A., Tsepliaev L.N. Novosibirsk v istoricheskom proshlom: konets XIX-nach XXv. [Novosibirsk in the historical past: the end of the XIX - early XX century]. Novosibirsk, nauka Publ, 1978. 293 p.

Gradostroitelstvo Rossii serediny XIX - nach XX v. Kniga 1. Obshhaya kharakteristika i teoreticheskie problemy. [Urban planning in Russia in the mid-XIX - the beginning of the XX century. Book 1. General characteristics and theoretical problems]. M., Progress-Tradiciya, 2001. $340 \mathrm{p}$.

Khramkov A.A. Arendnyye poselki v Altaiskom okruge v nach. XX v. [Rental settlements in the Altai region in the beginning. XX century]. Barnaul, Barnaul - 250 years., 1980. pp. 138-141.

Kukharenko A.E. Dorevolyutsionnaya i sovetskaya istoriografiya zemel'no-arendnoy politiki Kabineta v Altayskom (gornom) okruge/ Izvestiya Altayskogo gosudarstvennogo universiteta. Seriya: Istoriya, politologiya. Izvestiya Altaiskogo gosudarstvennogo universiteta. Series: History, politology [Pre-revolutionary and Soviet historiography of the land-lease policy of the Cabinet in the Altai (mountainous) district]. 2012, no.4/2, pp. 146-150. (in Russian).

Minina N.A. Obrazovanie goroda Novonikolaevkska: zemleustroistvo v 1893 - 1895 gg. Vestnik Tomskogo gosudarstvennogo universiteta [The origin of Novonikolaevsk: Land Planning from 1893 to 1895 ]. 2015, № 397, pp.147-153.

Novokshonov S.M. Gradostroitelnoe razvitie goroda Novonikolaevska (Novosibirska) s 1893 po 1917 gody [Urban development of the city of Novo-Nikolaevsk (Novosibirsk) from 1893 to 1917]. E.A. Kusnetsova [ed], Novosibirsk, GAY NSO NPC Publ., 2013. 148p.

Ryndzyunskiy P.G. Krestyane i gorod v kapitalisticheskoy Rossii vtoroy poloviny XIX veka. [Peasants and a city in capitalist Russia in the second half of the XIX century]. M., «Nauka», 1983. $268 \mathrm{p}$.

Senyavskiy A.S. Urbanizatsiya Rossii v XX veke: rol v istoricheskom protsesse. [Urbanization of Russia in the 20th Century: Role in the Historical Process]. M., 2003. 286 p.

Skubnevskiy V.A.. Goncharov Yu.M. Goroda Zapadnoy Sibiri vo 2-y polovine XIX - nachale XX vekov: Naselenie. Ekonomika. Zastroyka i blagoustroystvo. [Skubnevsky V.A., Goncharov Yu.M. Cities of Western Siberia in the 2nd half of the XIX - early XX centuries: Population. Economy. Building and landscaping]. Barnaul, «Az Buka», 2007. 252 p.

Umbrashko K.B. Chaus - Kolyvan - Novonikolaevksk: ironiya sudby. Istochnikovedchekiy aspect. Osvoenie i razvitie Zapadnoy Sibiri v XVI-XX v. Materialy mezhregionaln. nauchno-prakt. konf., posv. 300-letiyu Chausskogo ostroga. [Chaus - Kolyvan - Novonikolaevksk: the irony of fate. From the stand pound of source studies. The colonization and development of Western Siberia in the XVI-XX centuries. Materials of the interregional scientific-practical conference dedicated to the 300th anniversary of the Chaussky burg], Novosibirsk, Sibprint, 2013, pp. 109-110.

Vorobtsova L.N. Chastnoe predprinimatelstvo v Novonikolaevske (1893-1914) [Free enterprise in Novonikolaevsk (1893-1914)]. Novosibirsk: RIC NGY Publ., 2015. 436p. 